\section{Every \\ Outcome Counts}

\section{Jeden O. Tolentino}

Winnipeg, Manitoba

Jeden O. Tolentino is a historian-in-training. He moved to Canada from the Philippines in 2010. While pivoting from a career in the social sciences to one in the humanities, he has done research on the history of Filipinx immigration to Canada. He intends to pursue a PhD in cultural history.

\section{Keywords}

young immigrants, education \& training, science in art, art in science, STEAM 


\section{Artist Statement}

I approached the creation of these four graphics as a convergence of the skills and knowledge that I brought from my home country, the Philippines, and those that I have acquired in Canada. Combining abstract mathematics and visual art, I used concepts from graph theory, group theory, and probability theory to show a pictorial flow comparing the muddled situation in which young immigrants to Canada find themselves to the "optimal" albeit assimilated situation of those who have had time to settle (in multiple senses) into their new lives.

First, I used probability theory, which is the branch of mathematics that studies the possible outcomes of given events together with the outcomes' relative likelihoods and distributions (Weisstein, n.d. a), to control how the lines in each square cell meander and criss-cross. This involved drawing three parallel lines in each cell and then applying the concept of "random walk" to the points of each line so that they moved randomly away from the center in one direction or the other, thus curving the lines. Second, I used group theory, which is the study of mathematical objects that we encounter whenever we add and multiply (Rowland \& Weisstein, n.d.), to decide how I would flip and/or rotate each cell. This involved treating each cell as a "dihedral group" that can be rotated up to four times and flipped back and forth. Third, I used graph theory, which is the study of mathematical structures composed of points and lines (Weisstein, n.d. b), to determine how I would colour each cell. This involved using graph colouring theorems to ensure that no two adjacent regions within a cell share the same colour. For both the flipping, rotating, and colouring processes, I used a random number generator to randomize the outcomes.

The message of the four graphics depends on two notions of outcomes. On one hand, I built the graphics by using mathematical theory that considers 
all feasible visual possibilities. And on the other, I attempted to shed light on the commodification of the educational outcomes (or options) of young newcomers to Canada. My use of the term commodification here relates to the orientation of education systems in Canada towards a capitalist system that appropriates education outcomes as another good that it produces. In both my method and my aim, I argue that every outcome should count.

These four graphics are, thus, my visual representation of the multiplicity of the challenging road(s) that newcomers to Canada are expected to traverse when their skills from their education and training in their countries of origin are not fully recognized (if at all) by Canadian governmental, educational, and capitalist institutions. These same institutions have tackled this issue and have offered solutions. However, their focus has been on the plight of individuals entering the workforce and on how firms can avoid underutilizing or devaluing these individuals' skills. Regardless of the best intentions of these Canadian institutions, commodification is still a visible aspect of the immigration agenda both at the provincial, territorial, and the national levels. This is manifested in the federal and jurisdictional policies for recognizing the education outcomes of newcomers as well as in published reports. For example, Houle and Yssaad (2010) listed education level as one of the "characteristics deemed to be most likely to increase success in the Canadian economy" (p. 18). Similarly, whereas Wayland and Goldberg (2010) found that discriminatory deficiencies in Canadian immigration policy lead to "a loss to our own Canadian economy" (p. 2), Grant (2016) regarded improvements in learning recognition in terms of its potential to "recognize billions in economic benefit" (Preface).

Less visible in these policies and reports are the cases of younger immigrants who have found their years of schooling and their corresponding earned knowledge and skills discounted by the Canadian education system, if not completely wiped 
away. I have encountered a number of these cases in my time working in education in Canada, both in a teaching capacity and in a governmental role working on education statistics over the course of seven years for the province of Manitoba. In the primary and secondary levels, I witnessed how the education of young newcomers entering a Canadian public school system is reduced to a classification (i.e., the number of years near, above, or below the ageappropriate grade level for a Canadian pupil) whereby their entire careers as learners in their countries of origin, with all their inherent social, cultural, and economic specificities, are made to fit the Canadian system that seeks to eventually commodify the students' outcomes. At the post-secondary level, I witnessed how years of university training, even entire degrees, are othered by academic institutions, forcing newcomers to repeat much of what they accomplished in their countries of origin, often at considerable expense. This doubly disadvantages immigrants as they move from their learning careers to their professional careers in a capitalist society.

As a learner in addition to being a worker, I experienced challenges in accessing continuing education in Canada, particularly at the postsecondary level. These challenges forced me to pursue a re-education, whereby I will hopefully be able to shift towards a career that can challenge the system from the outside. My previous training as an economist and my experience within government have clarified the challenges imposed upon newcomers to Canada by a capitalist system that commodifies education outcomes. As a consequence, I can orient my ongoing training as a historian and vocation as an artist to challenge such a system. I fully recognize the privileged position I have found myself in over the decade I have been in Canada as well as the opportunities that I have received to work and to study. Thus, I aim to draw more attention to the issue with the graphics that I present here. 

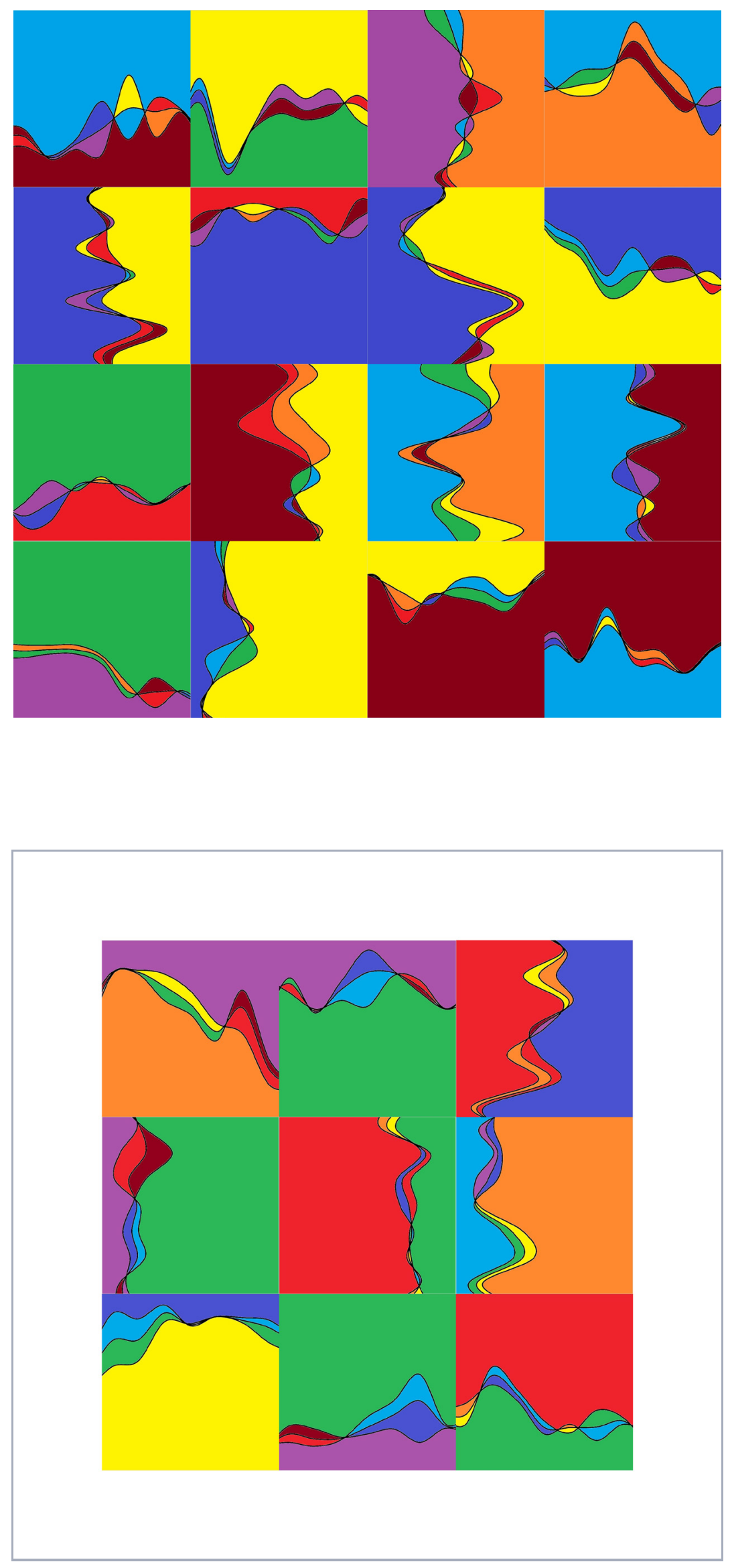


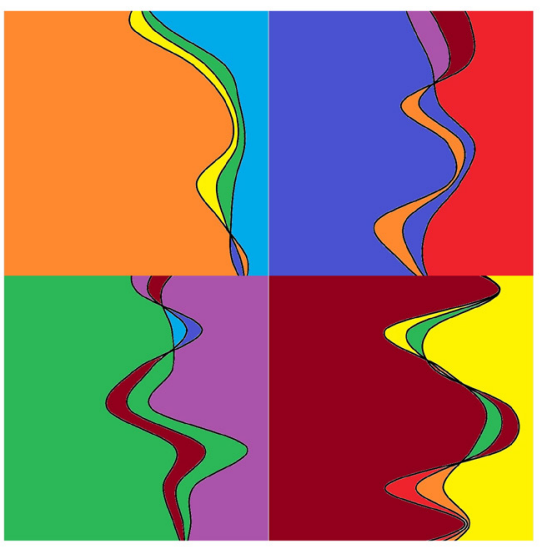




\section{References}

Grant, M. (2016, January). Brain gain 2015: The state of Canada's learning recognition system. The Conference Board of Canada. https://www.conferenceboard.ca/e-library/abstract. aspx?did=7607

Houle, R., \& Yssaad, L. (2010, September). Recognition of newcomers' foreign credentials and work experience. Statistics Canada. https://www150.statcan.gc.ca/n1/pub/75001-x/2010109/pdf/11342-eng.pdf

Rowland, T., \& Weisstein, E. W. (n.d.). Group. MathWorld. http:// mathworld.wolfram.com/group.html

Wayland, S., \& Goldberg, M. (2010, February). The recognition of immigrant skills: A search for best practices. Peel Halton. http://www.peelhaltonworkforce.com/sites/default/files/ The\%20Recognition\%20of\%20Immigrant\%20Skills.pdf

Weisstein, E. W. (n.d.). Graph. MathWorld. http://mathworld. wolfram.com/graph.html

Weisstein, E. W. (n.d.). Probability. MathWorld. http://mathworld. wolfram.com/probability.html 
